\title{
The Internet Blockage Policy in Indonesia: A Legal and Human Rights Perspective
}

\author{
Tundjung Herning Sitabuana ${ }^{1}$ Ade Adhari ${ }^{*}{ }^{*}$ Luisa Srihandayani ${ }^{2}$ \\ Imelda Martinelli ${ }^{1}$ Ida Kurnia $^{1}$
}

${ }^{1}$ Faculty of Law, Universitas Tarumanagara, Jakarta, 11440, Indonesia

${ }^{2}$ Faculty of Law, Universitas Diponegoro, Semarang, 50241, Indonesia

*Corresponding author. Email: adea@fh.untar.ac.id

\begin{abstract}
The government's policy to block the internet has become a debatable issue among societies whether it infringes on freedom of expression and freedom to seek, receive, and impart information or not. Therefore, this paper provides a description and analysis of the internet blockage issue according to Indonesia's Legal and Human Rights perspective. The research on this paper was done using normative legal research. The results of the analysis show that Indonesia's internet blockage policy infringes legal and human rights perspectives because there is no specific law that mentions the authority of the government to block the whole internet in riots caused by the spread of invalid information.
\end{abstract}

Keywords: Internet Blockage, Policy, Legal and Human Rights

\section{INTRODUCTION}

Internet blocking is one of Indonesia's government policies produced by the Ministry of Communication and Information Technology of the Republic of Indonesia (MCIT), which had been carried out several times, among others:

Table 1 Several internet blocking activities by the government in Indonesia

\begin{tabular}{llc}
\hline Internet Blockage & Timeline \\
\hline 1 & Telegram application service blocking & $\begin{array}{c}14 \text { July } \\
2017\end{array}$ \\
\hline 2 & $\begin{array}{l}\text { Restriction of social media usage } \\
\text { during the demonstration against the } \\
\text { result of the Presidential Election }\end{array}$ & $\begin{array}{c}22 \text { May } \\
2019\end{array}$ \\
\hline 3 & $\begin{array}{l}\text { Throttling or slowdown in } \\
\text { access/bandwidth in several areas in }\end{array}$ & 21 August \\
& $\begin{array}{l}\text { Papua where riots were taking places, } \\
\text { such as in Manokwari, Jayapura, and }\end{array}$ & 2019 \\
several other places & \\
\hline 4 & $\begin{array}{l}\text { Internet blackout in Wamena Papua, } \\
\text { by issuing Press Release No }\end{array}$ & 23 \\
$\begin{array}{l}\text { 187/HM/Kominfo/09/2019, regarding } \\
\text { Restrictions on Deptember } \\
\text { Wamena. Services in }\end{array}$ & 2019 \\
\end{tabular}

The basis argumentation used by Indonesia's Government in implementing the internet blockage is Article 40 paragraph (2a) and (2b) of Law Number 19 Year 2016 juncto Law Number 11 Year 2008 concerning Electronic Information and Transactions (EIT Law) [1], that states: "(2a) The government shall prevent the dissemination and use of Electronic Information and / or Electronic Documents that have prohibited according to the provisions of laws and regulations

(2b) In implementing prevention as referred to in paragraph $(2 a)$, the government has the authority to terminate access and/or order the electronic system operator to terminate access to electronic information and/or electronic documents in which content violates the law".

Other than that, the internet blockage by the government is also regulated in: (a) Law Number 71 Year 2019 concerning The Enforcement of Electronic Systems and Transactions, and (b) Ministry of Communication and Information Technology of the Republic of Indonesia Regulation Number 19 Year 2014 concerning Handling of Negatively Contained Internet Sites. According to the government, such actions were done to minimize the misuse of technology bywhich would affect the public order and security [1].

However, government's policy to block the internet has become a debatable issue among societies whether it infringes on freedom of expression and freedom to seek, receive, and impart information or not. Southeast Asia Freedom of Expression Network (SAFEnet), The Indonesia National Human Rights Commission, The United Nation High Commissioner for Human Rights (Michelle Bachelet) are some of the critics who represent that internet blockage policy in Indonesia is a form of 
human rights violation and more likely to exacerbate the riots tension $[2,3]$.

Based on the two perspectives above, this paper will further discuss the legal issue: "Internet blocking policy in Indonesia in the legal and human rights perspective", especially to find out whether a legal and human rights perspective allows internet blockage or vice versa.

\subsection{Our Contribution}

This paper presents new information regarding the legal and human rights perspective on internet blockage implementation in Indonesia whereby can be useful for broadening the horizons for readers as well as for future research material, not only for Indonesian ourselves but also for people all over the world who would like to do comparative legal research on this topic.

\subsection{Paper Structure}

The rest of the paper is organized as follows. Section 2 introduces the methodology used in this paper. Section 3 presents the result and discussion of legal and human rights perspectives regarding internet blockage policy in Indonesia. Ultimately, all of the analysis will be concluded in Section 4.

\section{METHODOLOGY}

The method used in this research is the normative legal research method. Normative legal research, also known as library research, is a legal research that believes that law is a building of norm system. The system of norms referred to the principles, norms, rules of legislation, court decisions, agreements, and doctrines [4]. This research is a descriptive-analytic research therefore it will be done by: (1) finding and describing the highlighted legal issue; (2) processing data and analyzing the issue; and (3) concluding the analysis. The approaches used to support this research are: (a) a statutory approach (the regulations) (b) a conceptual approach (the concepts in doctrine) and (c) a case approach (implementation of norms) [5]. Sources of legal materials used are: (a) primary legal materials (regulations of internet blockage) and (b) secondary legal materials (legal literature, articles, journals, and internet media) [6]

\section{RESULT AND DISCUSSION}

\subsection{Human Rights Perspective in Indonesia}

Discussion about the internet blocking conducted by the Government of Indonesia will eventually bring us to a "human rights issue" as Jack Donnely argued that human beings have basic rights that are not given by the positive law, but by having them naturally, because of their dignity as human [7]. The basic rights here are particularly freedom of expression and freedom to seek, receive, and impart information. Although human rights are seen as rights inherent in every human being, but in practice they are interpreted in various points of view. Muladi mentioned 4 (four) different perspectives on human rights, namely: (1) universal-absolute; (2) universal-relative; (3) particularistic-absolute, and (4) relative-particularistic [8]. These four views can briefly be described as follows:

a. Universal-absolute groups see human rights as universal values as formulated in The International Bill of Human Rights. They do not appreciate the sociocultural profile inherent in each nation.

b. The universal-relative group views human rights as a universal problem, however, some exceptions based on international legal principles are still recognized as being.

c. Particularistic-absolute, sees human rights as a matter of each nation, without giving strong reasons, especially when it comes to rejecting the validity of international documents.

d. Adherents of relative-particularism, view that the human rights issue is not only a universal problem but also a national problem of each nation. The validity of international documents must be harmonized, supported, and embedded in the nation's culture. This view is not only defensive, but also actively seeks to formulate and justify the characteristics of human rights that it adheres to.

The first fundamental question to begin with, is what kind of human rights perspective is adopted by The Republic of Indonesia. The answer to this question must be figured out based on the doctrinal-deductive method in the principle of the rule-systematizing logic of legal science as presented by Hans Kelsen [9].

Through doctrinal-deductive reasoning, it will be possible to know the views of human rights adhered to in the Indonesian legal system. Firstly, the "deductive reasoning" method will certainly lead to what is called a syllogism. Deductive inference usually uses a syllogistic mindset which is simply described as a compiler of two statements and a conclusion [10]. In other words, the syllogism is an indirect inference whose conclusion is drawn from only two premises. Thus, a syllogism is always composed of three propositions, two serving as premises, and one serving as a conclusion [11].

The Constitution of Republic Indonesia Year 1945 (Indonesia Constitution) is a positive self-evident norm that serves as the major premise and the main source to justify the views of human rights adhered to by the Indonesian people. Article 28J paragraph (2) of Indonesia Constitution as the major premise stipulates that:

"In exercising his rights and freedoms, everyone is obliged to comply with the restrictions established by law with the sole purpose of guaranteeing recognition and respect for the rights and freedoms of others and to fulfill fair demands in accordance with moral considerations, religious values, security and public order in a democratic society". 
The clause thereof can also be found in Article 70 of Law Number 39 Year 1999 concerning Human Rights (Human Rights Law) as derivative legislation of Indonesian Constitution pertaining to Human Rights matter.

Accordingly, it can be seen that the Indonesian Constitution places human rights as relative-particularistic, not universal absolute whereas it allows certain limitations and derogations including the freedom of expression and freedom to seek, receive, and impart information. In fact, if there are rights that can not be reduced under any circumstances, the state of Indonesia in Article 28I paragraph (1) only specifies some of the rights in it, namely: (1) The right to life; (2) the right not to be tortured; (3) the right to freedom of thought and conscience; (4) the right not to be enslaved, (5) the right to be recognized as a person before the law, and (6) the right not to be prosecuted on a retroactive legal basis. This view is in line with the global view as stated by the United Nations in one of its writings entitled International Norms and Standards Relating to Disability, that there are only 4 non-derogable rights within 3 (three) human rights conventions in the world (the International Covenant on Civil and Political Rights (ICCPR), the European Convention on Human Rights and the American Convention on Human Rights), namely: (1) the right to life, (2) the right to be free from torture and other inhumane or degrading treatment or punishment, (3) the right to be free from slavery or servitude and (4) the right to be free from retroactive application of penal laws that should not be violated under any circumstances [12]. So, it is clear that the right to freedom of expression and freedom to seek, receive, and impart information can be limited by the state.

\subsection{The Limitation and Derogation of Freedom of Expression and Freedom to Seek, Receive, and Impart Information and The Practice in Indonesia}

Before discussing the specific act and technical matters under it, Indonesia has actually ratified the ICCPR with Law Number 12 Year 2005 concerning Ratification of the International Covenant on Civil and Political Rights. This shall mean that this convention could be used as a guideline in establishing human rights limitation, particularly regarding the right of freedom of expression and freedom to seek, receive, and impart information as mention in Article 19 ICCPR among others:
1. Everyone shall have the right to hold opinions without interference.

2. Everyone shall have the right to freedom of expression; this right shall include freedom to seek, receive and impart information and ideas of all kinds, regardless of frontiers, either orally, in writing or in print, in the form of art, or through any other media of his choice

3. The exercise of the rights provided for in paragraph 2 of this article carries with it special duties and responsibilities. It may therefore be subject to certain restrictions, but these shall only be such as are provided by law and are necessary:

a. For respect of the rights or reputations of others;

b. For the protection of national security or of public order, or of public health or morals.

Hence, it can be said that it is not adequate to limit or derogate the freedom of expression and freedom to seek, receive, and impart information rights only based on the approval of the state to reduce or limit some rights. The guideline provided by ICCPR altogether with the Siracusa Principle as an explanation of the principles for derogating and limiting the ICCPR's human rights, especially Articles 22-30 and Article 37 states, also concerns to how the state derogates and limits those rights. For the matter of "how the state derogates and limits" the rights, there are 3 (three) main indicators that have to be satisfied, among others:

1. Prescribe by the law;

2. The purpose of the limitation;

a. To guarantee recognition and respect for the rights and freedoms of others, and to fulfill fair demands

b. To ensure the functioning of society or the set of fundamental principles on which society is founded

c. Aimed at preventing disease or injury or providing care for the sick and injured.

d. For the benefit of public morals; or

e. To protect the existence of the nation or its territorial integrity or political independence against force or threat of force

3. Done with the following considerations:

a. Morals, religious values, security and public order in a society; and

b. Shall not be used to protect the state and its officials from public opinion or criticism.

Next, it is important to observe how the derogation and limitation of freedom of expression and freedom to seek, receive, and impart information rights in Indonesia internet blocking is implemented based on the three criteria provided by the ICCPR above.

Table 2 Derogation and limitation of freedom of expression and freedom to seek, receive, and impart information rights in Indonesia internet blocking based on 3 (three) main indicators by ICCPR

\begin{tabular}{lll} 
Indicators & \multicolumn{1}{c}{ Fact } & \multicolumn{1}{c}{ Explanation } \\
Prescribed & The laws governing blocking on the Internet & \multicolumn{1}{c}{ The phrase "The government shall prevent the } \\
by the law & $\begin{array}{l}\text { according to the government, namely: Article } \\
40 \text { paragraph }(2 \mathrm{a}) \text { and }(2 \mathrm{~b}) \text { of the EIT Law, }\end{array}$ & $\begin{array}{l}\text { or Electronic Documents" actually shows that what is } \\
\text { being prevented is the content of a site on the internet, } \\
\text { but not the internet. }\end{array}$ \\
& $\begin{array}{ll}71 \text { of } 2019 \text { concerning Implementation of }\end{array}$
\end{tabular}


Electronic Systems and Transactions states that:

- The government shall prevent the dissemination and use of Electronic Information and/or Electronic Documents that have prohibited content according to the provisions of laws and regulations

- In implementing prevention, the government has the authority to terminate access and/or order the electronic system operator to terminate access to electronic information and/or electronic documents in which content violates the law.

Aim a. To guarantee recognition and respect for the rights and freedoms of others, and to fulfill fair demands;

b. To ensure the functioning of society or the set of fundamental principles on which society is founded

c. Aimed at preventing disease or injury or providing care for the sick and injured.

d. For public morals; or

e. To protect the existence of the nation or its territorial integrity or political independence against force or threat of force
- The phrase "terminate access and/or order the electronic system operator to terminate access to electronic information" also shows that the object to be terminated is the interaction with the electronic system on the information concerned.

- State Administrative Court Decision Number 230 / G / TF / 2019 / PTUN / Jkt in its decree also stated the two things above as a consideration which means that Indonesian law only allows termination of access to information or sites, not to the entire internet network (p. 265 ).

The internet blocking by the government is actually carried out every time some hoaxes are spread, which triggers a riot. This can be seen:

a. During the presidential election, there was a hoax stating that the police fired at the crowd, even though the Head of the Public Relations Division of the National Police, Brigadier General (Pol), Dedi Prasetyo, said that the police officers were not equipped with live ammunition to secure the demonstration. The hoax was definitely arranged to create a scenario of chaos, security forces attack, and antipathy emergence to the government [13].

b. The channels in the telegram service were blocked because they contained propaganda of radicalism, terrorism, hatred, such as calls or how to build bombs, how to carry out attacks, disturbing images, and so on [14].

Although the limitation does not comply with the first criteria, however, these situations show that the government use it for a good purpose.

\footnotetext{
Consider- a. Morals, religious values, security and

$\begin{array}{ll}\text { ation } & \text { public order in a society } \\ \text { b. Shall not be used to protect the state and its }\end{array}$ officials from public opinion or criticism.

Fulfilled, as can be seen in the use of internet blocking in the cases above.
}

Based on the table mentioned before, it can be said that the derogation and limitation of freedom of expression and freedom to seek, receive, and impart information rights in Indonesia are satisfied the ICCPR Indicators, except for prescribe by the law. As a result of not fulfilling this one provision, even though the aim of the government is correct, the internet blockage action is certainly cannot be justified and is very prone to arbitrariness. Apart from the legal basis of the Electronic Information and Transactions and the negative content above, Indonesia actually has instruments that restrict or prohibit the use of communication tools. This can be seen from Article 17 paragraph (3) Government Regulation in lieu of Law Number 23 of 1959 concerning the Revocation of Law Number 74 of 1957 and the Stipulation of A State of Emergency (Perpu 23/1959) which states that:

"The civil emergency authorities have the right: to enact regulations that restrict or prohibit the use of telecommunication equipment, such as telephones, tilgrap, radio transmitters and other devices which are connected to radio broadcasting and which can be used to reach the general population, as well as confiscate or destroy the equipment "

Nevertheless, the use of this rule is only permitted under the terms and conditions of a civil emergency or military emergency, or war emergency, as stated in Article 1 of Perpu 23/1959, among others: (1) there are rebellions, riots, or natural disasters which threatened the security or legal order throughout the territory of Indonesia; (2) there is war or danger of war; (3) there are special circumstances that could endanger the life the state. In addition, before taking any action, these incidents or potential incidents must be announced first by the president/commander-in-chief of the armed forces.

Perpu 23/1959 corresponds with Article 4 of the ICCPR which states:

"In time of public emergency which threatens the life of the nation and the existence of which is officially proclaimed, the States Parties to the 
present Covenant may take measures derogating from their obligations under the present Covenant to the extent strictly required by the exigencies of the situation, provided that such measures are not inconsistent with their other obligations under international law and do not involve discrimination solely on the ground of race, color, sex, language, religion or social origin."
By far, MCIT had done press releases to notify throttling. However, it obviously did not fulfill the requirement of Article 2 paragraph (2) Perpu 23/1959 which stated that the announcement is done by The President of Republic Indonesia.

\subsection{Comparative Studies}

Comparatively, internet blocking is also carried out in several other countries, for example, India and Africa which can be described as follows:

Table 3 Internet Shutdown Comparative Summary in India and Africa (Lesotho and Congo)

\begin{tabular}{ll} 
Country & Aspect \\
\hline India & Regulation
\end{tabular}
Explanation

India Regulation • Before $2017 \rightarrow$ the Indian Telegraph Act 1885

- August $2017 \rightarrow$ the Government of India issued additional rules namely the Temporary Suspension of Telecom Services (Public Emergency or Public Safety) Rules, as a derivative and complement rules of the Indian Telegraph Act 1885

Procedure 1. Directions to suspend the telecom services shall not be issued except by an order made by the Secretary to the Government of India in the Ministry of Home Affairs (hereinafter referred to as the competent authority), and in unavoidable circumstances, where obtaining prior direction is not feasible, such order may be issued by an officer, not below the rank of a Joint Secretary to the Government of India, who has been duly authorized by the Union Home Secretary or the State Home Secretary.

2. The Central Government or the State Government, as the case may be, shall also constitute a Review Committee to observe and ensure the action is done appropriately.

Goals [15] To prevent the transmission of any kind of message during the specific event which threatens: (1) sovereignty and integrity of India; (2) security of the State; (3) friendly relations with foreign states; (4) public order; or (5) preventing incitement to the commission of an offense.

Example 1. In Ambatenna (Sri Lanka), mobs (reportedly from a Sinhalese Buddhist Community) attacked of cases and ruined many homes and businesses of the Muslim community. They used Facebook, [16] WhatsApp, and Viber to spread rumors about Muslims and instigate the attacks. Authorities in Sri Lanka, seeking to end the violence, blocked access to Facebook, WhatsApp, and other social media platforms for more than a week.

2. In two North Eastern regions of India, there are rumors of child-lifting gangs[6] that led to a series of lynchings, with more than 30 deaths. In order to stop the spreading of the rumors, the authorities shut down internet services twice.

\begin{tabular}{|c|c|c|}
\hline \multirow[t]{2}{*}{$\begin{array}{l}\text { Africa } \\
\text { (Lesotho } \\
\text { and } \\
\text { Congo) } \\
{[17]}\end{array}$} & Regulation & $\begin{array}{l}\text { - Lesotho (Country of Eastern Africa): Lesotho National Assembly Electoral Act, Lesotho } \\
\text { Communication Act } 2012 \text { Article } 20 \text {. } \\
\text { - Congo (country od central Africa) : Act No. } 13 \text { of } 2002 \text { Postal and Telecommunications } \\
\text { Regulatory Authority Act No. } 14 \text { of } 2002\end{array}$ \\
\hline & Procedure & $\begin{array}{l}\text { - Lesotho: } \\
\text { - No licensee shall be prevented or impeded, either directly or indirectly, from providing } \\
\text { service, unless either (a) the Authority has suspended or revoked the licensee's licence; or } \\
\text { (b) the Minister issues an emergency suspension order. } \\
\text { - Refer to point b, Lesotho legislation stressed that the minister shall only issue this } \\
\text { emergency suspension order if there is a reasonable ground to conclude that the } \\
\text { continuation of the licensee operation poses a substantial, direct, and imminent threat to } \\
\text { national security or public order and that there is no other way to forestall the threat other } \\
\text { than to act that way. } \\
\text { - Any emergency suspension order by the minister shall be provided: (a) in writing; (b) with } \\
\text { the explanation of the suspension basis; and (c) it remains in effect for no more than } 72 \\
\text { hours, unless extended by a court of competent jurisdiction. } \\
\text { Congo: } \\
\text { "The State may [...], prohibit in whole or in part, and during the time determined, the use of } \\
\text { telecommunications facilities. The State may also, in the cases referred to in the first paragraph } \\
\text { of this section, requisition the telecommunications facilities. The people usually serving these } \\
\text { facilities may be required to render their services to the competent authority if they so require } \\
\text { it. }\end{array}$ \\
\hline
\end{tabular}




\begin{tabular}{ll} 
Goals & - Lesotho: the goal is to prevent any threat to national security or public order of the country \\
& - Congo: the goal is to guard the public security or defence of the territory \\
\hline $\begin{array}{l}\text { Example } \\
\text { of Cases }\end{array}$ & $\begin{array}{l}\text { There was an internet blocking from } 31 \text { December } 2018 \text { - January } 2019 \text { in Congo due to attempt to } \\
\text { dampen speculation about the presidential election results. [18] }\end{array}$
\end{tabular}

From the table above, the characteristics of internet shutdowns in countries such as India, Lesotho and Congo seem to have similarities with Indonesia, whereby:

1. It is prescribed by the law

2. There are parties who give orders and implement internet blocking

3. Considerations, such as public or national security or public order

The difference with Indonesia lies in the provisions of the law which explicitly states that the Indian government has the right to undertake "suspension of telecommunications services", which is the same as Congo with the phrase "use of telecommunications facilities".

Several countries also show signs of court trials stating that the provisions regarding the right to express opinions, communication and information are contrary to human rights. This can be seen in Pakistan and Zimbabwe, as follows:

a. Pakistan [19]

Pakistan frequently orders internet shutdowns that suppress all digital communications across the whole city. This can be done in the short and long term depending on the reason. Ben Wagner mentioned, within the short-term shutdowns (typically will be held for one day up to a week), internet shutdowns generally can be categorized by 5 (five) events, those are:

1. National holidays, for instance, Pakistan Independence Day;

2. Religious holidays;

3. Large political marches, strikes, or sit-ins in the country;

4. High-level political events, such as the visit of the Chinese prime minister or the Command change in the Armed Forces;

5. Perceived security threats, commonly unspecified, but it requires internet shutdown as a precaution.

Besides the short-term shutdown, Pakistan also practice long-term shutdowns bywhich commonly take place for several weeks up to months. Two of the most recent example of long term shutdowns are:

1. The suspension of all phone service in the entire tribal region since 15 March 2017 until four months later without reasonable ground or notification.

2. The suspension of internet services in Dalbandin city (Balochistan Region) in February 2017 which has been done for six months without a clear basis or notification about when the internet services would be restored.
The process for ordering an internet shutdown is also not transparent and highly authoritarian. On 26 February 2018, the Pakistan High Court declared Internet shutdowns in Pakistan "as an illegal and disproportionate response to security threats". The judgment suggests that the concept of national security is being overextended and that justifying Internet shutdowns using "apprehensions relating to public safety, law, and order or the happening of an untoward incident". Internet shutdowns could only be justified under a national state of emergency following an official "Proclamation of Emergency by the President of Pakistan"

b. Zimbabwe [17]

In Zimbabwe, the provision of internet shutdown can be seen from the Postal and Telecommunications Act bywhich states: "If in the opinion of the President it is necessary in the interests of national security or the maintenance of law and order, he may give a direction that ... (a) any cellular telecommunication or telecommunication service established, maintained or worked by a cellular telecommunication or telecommunication licensee or any class of such services shall be suspended or that such service shall be suspended in respect of a person named in the direction".

Regarding this provision, the constitutional court states that:

1. The act shows lack of accountability mechanism since no clause can control or limit the exercise of the President's power. This kind of power can potentially lead to an unfettered discretion by the President to intercept mail and communication;

2. The act has no guidance as to what a citizen should do or not do to avoid the abuse of the president power;

3. The act has no legal recourse or safeguards for the innocent whereas it is quite different to similar legislation in other jurisdictions bywhich is required to provide prior scrutiny, independent supervision, and effective remedies for abuse of the powers.

The judges are convinced that the absence of such accountability mechanism has made the president's power too broad and overreaching to be reasonably justified in a democratic society. Thus, the judge said the impugned sections of the act are too vague and do not satisfy the constitutional requirement of 'provided by law'.

Based on the facts above, the provisions regarding internet shutdown commonly are not allowed when: 
1. Those who do not have clear procedures;

2. Performed arbitrarily for no apparent reason.

If these two reasons are contextualized with Indonesia, in fact Indonesia is not included in both. As previously mentioned, the problem in Indonesia is that there is no law that explicitly allows the government to block the internet to deal with riots or ward off ordinary hoax news which is not in a dangerous situation.

\subsection{The Future of Internet Blocking in Indonesia}

From the authors point of view, if in the future Indonesia needs the internet blocking policy to maintain conducive conditions within the country which is not categorized in state emergency, then the legal rules have to be established first. However, it is important to note that even though normatively, internet blocking is a constitutional policy to be carried out by the government, this policy should be used as the last resort in preventing the misuse of electronic information or electronic documents. This is because to be able to think that the news or notification is a lie is not easy. It requires "digital verification skills in order to find out whether videos, pictures, news on digital content are not something that contains lies".

According to Tom Trewinnard in his writing entitled "News Verification Guide", the verification process can be done through:

a. Doing a reverse image search on Google Image Search or TinEye;

b. Checking for scraped videos with Amnesty's Data Viewer;

c. Checking for consistency in shadows and reflection;

d. Speaking to the source, ask them to send you the original le (which should have EXIF data);

e. For images, use image analysis and authentication tools like Izitru or Forensically to detect any digital manipulation (this works best with the original les i.e. not those uploaded to social media).

This is how digital verification skills must be taught, so that people understand the process of verifying content spread across the internet.

\section{CONCLUSION}

In conclusion, the internet blocking policy in Indonesia is a constitutional policy because the Indonesian Constitution adheres to particularistic-relative views bywhich allows the states to derogate and limit such human rights. However, ICCPR and Siracusa mention that the limitation and derogation of human rights including freedom of expression and freedom to seek, receive, and impart information rights have to satisfy three criteria those are (1) prescribed by the law; (2) to guarantee recognition and respect for the rights and freedoms of others, and to fulfill fair demands, public morality, public health, and public security; (3) consider : morals, religious values, and shall not be used to protect the state and its officials from public opinion or criticism. Indonesia failed to fulfill one of the criteria that is prescribed by the law because EIT Law only allows the government to terminate access to the electronic information or document, but not the whole internet access. Therefore, State Administrative Court Decision Number 230 / G / TF / 2019 / PTUN / Jkt decided that the government internet blocking in Papua is illegal. In the future, if there is an important necessity, Indonesia should establish the law first. However, it is better that the policy should be used as the ultimum remedium or the last resort. The most important thing to do is to provide an understanding of digital verification skills, so that the societies are able to verify every information content circulating in cyberspace.

\section{REFERENCES}

[1] Ministry of Communication and Information of Republic of Indonesia, in: Block Is Not To Oppress, Jakarta, 24 July 2017, Available from: https://kominfo. go.id/content/detail/10151/blokir-bukan-untukmenindas/0/sorotan_media.

[2] CNN Indonesia, in: Internet Blocking, 21st Century Government Tool of Repression, 24 September 2019, Available from: https://www.cnnindonesia.com/ teknologi/20190924102034-185-433288/pemblokiraninternet-alat-represi-pemerintah-abad-21.

[3] A. Ramadhan, in: National Human Rights Commision: Internet Blocking in Papua Violates Human Rights, 26 August 2019, Available from : https://nasional.kompas.com/read/2019/08/26/1537272 1/komnas-ham-pemblokiran-internet-di-papuamelanggar-ham

[4] Mukti F N D dan Yulianto A, Dualism of Normative and Empirical Legal Research, Pustaka Pelajar, Jakarta, 2010 , p. 34

[5] Johni I, Theory and Metodhology of Normative Legal Research, Bayumedia, Jakarta, 2007, p. 300.

[6] Bambang S, Legal Research Metodhology, Rajagrafindo Persada, Jakarta, 2006, p. 112.

[7] Jack D, Universal Human Rights in Theory and Practice, Cornell University Press, London, 2003 pp. 721.

[8] Bagir M, People's Position, Human Rights and The Rule of Law, Gaya Media Pratama, Gaya Media Pratama, 1996, pp. 113-115. 
[9] Shidarta, Law of Reasoning and Legal Reasoning: Book 1 Philosophical Roots, Genta Publishing, Yogyakarta, 2013, p. 199.

[10] Fajlurrahman J, Legal Logic, Prenadamedia Group, Jakarta, 2019, p. 49.

[11] Arief S, Introduction to Logic: A First Step to Introducing the Field of Study, PT Refika Aditama, Bandung, 2018, p. 43.

[12] United Nations, in: International Norms and Standars Relating to Disability, Part II. International Human Rights System, United Nations Enable, Avalaible from: https://www.un.org/esa/socdev/enable/ comp210.htm.

[13] Oik Y, in: Wiranto: The Government Deliberately Restricts Social Media Today, 22 May 2019, Kompas, Available from: https://pemilu.kompas.com/read/2019/ 05/22/14291067/wiranto-pemerintah-sengaja-batasi-

media-sosial-hari-ini

[14] Yoga H. W, in: The Reason of Indonesia Government Blocked Telegram, 15 July 2017, Kompas, Available from: https://tekno.kompas.com/read/2017/ 07/14/20495927/ini-alasan-pemerintah-blokir-telegram

[15] SFLC.in, Living in Digital Darkness: A Handbook on Internet Shutdowns in India, SFLC.in, New Delhi, 2018, p. 13.

[16] Keepiton, The State of Internet Shutdowns Around The World, The 2018 \#Keepiton Report, Available from: https://www.accessnow.org/cms/assets/uploads/ 2019/07/KeepItOn-2018-Report.pdf

[17] Southern Africa Litigation Centre, Report: Navigating Litigation during Internet Shutdowns in Southern Africa, Africa, pp. 8-32. Available from: https://www.southernafricalitigationcentre.org/wpcontent/uploads/2019/08/SALC-Internet-ShutdownGuide-FINAL.pdf.

[18] Joseph Kabila, in: DR Congo Internet Restored After 20-Day Suspension Over Elections, 20 January 2019. Available from: https://www.aljazeera.com/news/ 2019/1/20/dr-congo-internet-restored-after-20-daysuspension-over-elections

[19] Ben Wagner, Understanding Internet Shutdowns: A Case Study from Pakistan, International Journal of Communication 12 (2018), pp. 3917-3928. 